УДК 582.272:577.115.3:577.1

\title{
ЛИПИДЫ И ФОТОСИНТЕТИЧЕСКИЕ ПИГМЕНТЫ РАЗНЫХ ЧАСТЕЙ ТАЛЛОМА ВОДОРОСЛЕЙ РОДА SACCHARINA
}

\author{
() Н.И. Герасименко , С.В. Логвинов, Н.Г. Бусарова
}

\author{
Тихоокеанский институт биоорганической химии им. Г.Б. Елякова \\ Дальневосточного отделения РАН, пр. 100 лет Владивостоку, 159, \\ Владивосток, 690022 (Россия), e-mail:gerana@piboc.dvo.ru
}

\begin{abstract}
Исследовали распределение липидов и фотосинтетических пигментов (ФСП) в разных частях пластины - апикальной, середине пластины, интеркалярной меристеме, а также в стволике с ризоидами 2 видов сахарин Японского моря - Saccharina cichorioides (Miyabe) и S. angustata (Kjellman) с листовидными не рассеченными пластинами и 2 дигитатных видов сахарин $S$. dentigera (Kjellman) и $S$. bongardiana (Postels et Ruprecht) Охотского моря. B S. cichorioides дополнительно исследовали изменения в содержании липидов и ФСП в частях пластины в начале роста водоросли и в стадии его завершения. Обнаружены значительные различия в распределении суммарных липидов (СЛ), их отдельных классов, жирных кислот (ЖК) и ФСП в разных частях таллома, которые имели видовые особенности и определялись условиями обитания и стадией развития водоросли, скорее, чем морфологией таллома. В завершивших рост S. cichorioides, в отличие от водорослей, начавших рост, происходило увеличение содержания липидов во всех частях пластины, а в стволике с ризоидами - понижение. Наряду с этим происходило перераспределение в частях пластины содержания всех классов липидов и ФСП, насыщенных (НЖК) и ненасыщенных (ННЖК) ЖК: содержание первых резко убывало в апикальной части и в середине пластины, а ННЖК - увеличивалось. Такие перестройки, скорее всего, были связаны с подготовкой водоросли к последующей стадии спорогенеза.

Ключевые слова: Saccharina, бурые водоросли, жирные кислоты, глицерогликолипиды, фосфолипиды, триацилглицерины, фотосинтетические пигменты, свободные стерины, газожидкостная хроматография.
\end{abstract}

Работа поддержана Грантом РНФ № 14-25-00037, РФ.

\section{Введение}

Содержание многих веществ - углерода, азота, фосфора и органических веществ (белки, аминокислоты, маннит, ламинаран), как показано многими исследователями, зависит не только от сезона [1-4], но и от локализации в пластине $[2,5]$. Изменения в содержании углерода, азота и запасных углеводов часто используют как индикатор роста и фотосинтеза в водорослях. Распределение липидов и жирных кислот, фотосинтетических пигментов в пределах пластины, стволике и ризоидах изучено в весьма ограниченном числе видов, в основном в бурых водорослях, которые характеризуются относительно четкой тканевой дифференциацией, помогающей водорослям успешно выживать в быстро изменяющихся окружающих условиях. Исследованы продольные профили пигментации в бурых водорослях Ascoseira mirabilis [6] и Saccharina japonica [5] и распределение липидов на протяжении таллома в Laminaria japonica (=S. japonica) [7], а также в 2 зонах таллома (нижней и верхней) Sargassum miyabei [8]. В бурой водоросли Ecklonia тиratii исследовано распределение

Герасименко Наталья Ивановна - начальник химикотехнологического участка, кандидат биологических наук, e-mail: gerana@piboc.dvo.ru

Логвинов Степан Викторович - младший научный сотрудник лаборатории пептидов, e-mail: logvinov@piboc.dvo.ru Бусарова Наталья Германовна - старший инженер лаборатории химии липидов и углеводов, e-mail: technolog@ piboc.dvo.ru
ЖК в стволике и в слоевище [9], а в Undaria pinnatifida - в срединном ребре пластины, в пластине и в ризоидах [10].

Исследование распределения разных классов липидов, жирных кислот и фотосинтетических пигментов, а также изменений в распределении этих веществ в разных зонах таллома в ходе его

\footnotetext{
* Автор, с которым следует вести переписку.
} 
роста, позволяют получить представление об их роли в дифференцированных тканях бурых водорослей и в ростовых процессах таллома.

В работе представлены результаты исследования особенностей распределения липидов, ЖК и ФСП в разных частях пластины и в стволике с ризоидами четырех видов бурых водорослей рода Saccharina из разных мест обитания.

\section{Экспериментальная часть}

Бурые водоросли сем. Laminariaceae: S. cichorioides (Miyabe) C.E. Lane, C. Mayes, Druehl et G.W. Saunders (=L. cichorioides) и S. angustata (Kjellman) C.E. Lane, C. Mayes, Druehl et G.W. Saunders (=L. angustata) были собраны в бухте Троицы (Японское море, Приморский край), а Saccharina dentigera (Kjellman) C.E. Lane, C. Mayes, Druehl et G.W. Saunders (=Laminaria dentigera) и Saccharina bongardiana (Postels et Ruprecht) Selivanova, Zhigadlova et G.I. Hansen (=Laminaria bongardiana) были собраны в бухте Крашенинникова острова Парамушир (Курильская гряда, Охотское море) во время экспедиции судна Академик Опарин. Водоросль S. cichorioides была собрана 12 марта и 14 июня, а остальные - 8-9 августа. Для анализа брали по 3 водоросли (длина таллома $-0,7-1,0$ м), a S. angustata -5 образцов (длина таллома 0,4-0,5 м). У водорослей брали стволик с ризоидами и 3 части пластины - нижнюю (интеркалярная меристема, около 6 см от границы стволик-пластина), середину пластины и верхнюю часть (апикальная часть, до 3 см от края пластины).

Экстракцию липидов проводили по методу Блайя и Даера [11]. Экстракты хранили при $-25{ }^{\circ} \mathrm{C}$ в герметично закрытых колбах. Анализ глицерогликолипидов (ГЛ) и нейтральных липидов (НЛ) выполняли

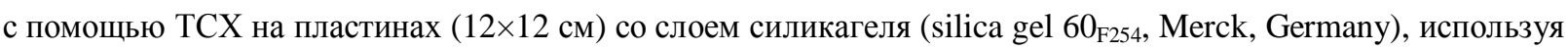
системы растворителей: ацетон - бензол - $\mathrm{H}_{2} \mathrm{O} 91: 30: 8$ (об./об.) - для ГЛ и гексан - диэтиловый эфир уксусная кислота $80: 20: 1$ (об./об.) - для НЛ. Содержание индивидуальных классов ГЛ, НЛ определяли методами, описанными нами ранее [12]. Суммарное содержание фосфолипидов (ФЛ) определяли по количеству фосфора, описанным ранее методом [12].

Количественное определение хлорофиллов и каротиноидов проводили после разделения суммарных липидов (СЛ) методом ТСХ, как описано нами ранее [12], и измеряя поглощение на спектрофотометре СФ-2000 при 450 нм для каротиноидов и 666 нм для хлорофиллов.

Метиловые эфиры ЖК (МЭЖК) получали переэтерификацией липидов, как описано нами ранее [12] и анализировали методом ГЖХ на газовом хроматографе Agilent 6890 (США) с пламенно-ионизационным детектором, оснащенном капиллярной колонкой HP-Innowax (30 м $\times 0,25$ мм $\times 0,25 \mu \mathrm{M})$; газ-носитель гелий, скорость потока $-1,2$ мл/мин. Для анализа МЭЖК использовали температурные градиенты: $60^{\circ} \mathrm{C}$ 2 мин, с последующим нагреванием до $200{ }^{\circ} \mathrm{C}$ со скоростью $10^{\circ} \mathrm{C}$ в мин, далее до $240{ }^{\circ} \mathrm{C}$ со скоростью $5{ }^{\circ} \mathrm{C}$ в мин и выдерживали при $240^{\circ} \mathrm{C} 10$ мин. Индивидуальные пики МЭЖК идентифицировали сравнением времен удержания с таковыми аутентичных стандартов, лабораторных стандартов ЖК и по значению эквивалента длины цепи [13].

Средние значения (в \%) и их стандартные отклонения для каждого анализируемого компонента были подсчитаны по трем повторным анализам с использованием компьютерной программы Microsoft Excel. Данные в таблицах 1-4 приведены как средние значения. Стандартные отклонения, составляющие порядка $\pm 0,01-1,0 \%$ от среднего значения не приводим.

\section{Результаты и обсуждение}

У высокоорганизованных водорослей рода Saccharina таллом разделен на органы прикрепления к субстрату, стволик и «листовидную» пластину. Зона роста (интеркалярная меристема) расположена в базальной части слоевища между стволиком и пластиной. В этой зоне происходит формирование новой ткани пластины. Разрушение пластины, идущее одновременно с ее нарастанием, происходит в верхней (апикальной) части. Исследуемые водоросли рода Saccharina по морфологии таллома разделили на 2 группы: первая группа включала водоросли S. cichorioides и S. angustata с не рассеченными линейными пластинами, вторая группа - водоросли S. bongardiana и S. dentigera с рассеченными на лопасти пластинами (дигитатные виды). Использовали водоросли с не поврежденными пластинами (исключение составили S. dentigera, у которых апикальная зона была местами повреждена), не репродуцирующие, так как у ламинариевых водорослей в этот период процессы деструкции преобладают над процессами роста.

Оптимальным диапазоном температур для роста спорофитов является $1-13{ }^{\circ} \mathrm{C}$, когда рост происходит при низких условиях освещенности, но высокой активности фотосинтеза. Нарастание пластины осуществляется 
делением и растяжением клеток меристемы. Главными органическими индикаторами морфо-функциональной активности считают уровни маннита и ламинарана в слоевище большинства бурых водорослей [14]. Маннит и в меньшей степени ламинаран достигают более высоких значений летом, когда рост водорослей уменьшается [14] и увеличение его содержания отражает активный синтез и хранение [2]. Использование маннита происходит весной во время быстрого роста водорослей для формирования биомассы. Роль липидов в ростовых процессах и их локализация в разных частях таллома водорослей практически не изучены.

Для исследования распределения липидов в талломе брали образцы S. cichorioides в начале роста (март, температура воды около $2^{\circ} \mathrm{C}$ ) и в период снижения скорости роста пластины (июнь, температура воды была в пределах $\left.11^{\circ} \mathrm{C}\right)$.

B S. cichorioides (сбор в марте) самое высокое содержание липидов было в нижней зоне пластины в интеркалярной меристеме. Середина пластины содержала немного меньше СЛ, еще меньше - апикальная зона (табл. 1). Распределение классов липидов в пластине также было неравномерным (табл. 1). Концентрация глицерогликолипидов уменьшалась от апикальной зоны к меристеме, а фосфолипидов, напротив, увеличивалась. Нейтральные липиды, в частности триацилглицерины (ТАГ), в большей степени концентрировались в середине пластины и в меристеме, тогда как в апикальной части их содержание было ниже. Высокий уровень содержания липидов и их отдельных классов, в частности, ТАГ и ФЛ в меристеме, находили в период, когда скорость и интенсивность роста водоросли были низкими. Адаптация к относительно низкому уровню освещенности ранней весной выражалась в увеличении площади фотосинтетических мембран в основном за счет середины пластины и ее верхушки, где шло накопление ФСП и ГЛ (табл. 1). Середина пластины содержала больше хлорофиллов, тогда как в апикальной части их содержание было немного ниже, а доля каротиноидов существенно выше. Устойчивый прирост хлорофилла весной отмечали ранее, например, в Laminaria hyperborea, что соответствовало увеличению ее фотосинтетического потенциала [15]. В ГЛ S. cichorioides весной преобладали, в первую очередь, моногалактозилдиацилглицерины (МГДГ), сульфохиновозилдиацилглицерины (СХДГ), которые распределялись в порядке убывания содержания от апикальной зоны к меристеме. В пластине дигалактозилдиацилглицерины (ДГДГ) распределялись относительно равномерно и содержание их было не высоким (табл. 1).

Водоросль S. cichorioides активно растет в апреле-мае. В июне после завершения стадии активного линейного роста в ней происходило значительное накопление липидов: зона меристемы увеличивала содержание СЛ в 2,5 раза, середина пластины и верхушка - в 1,3 раза по сравнению с водорослями марта (табл. 1). Увеличение содержания СЛ, как и в водорослях, собранных в марте, происходило от верхушки пластины к меристеме (табл. 1), тогда как в S. јароnica (сбор в июне) [7], верхушка пластины и меристема имели более низкий уровень СЛ, чем его середина. Профиль распределения классов липидов и ФСП по пластине в S. cichorioides отличался от такового в образцах марта. В меристеме и в середине пластины происходило увеличение содержания ГЛ и ФЛ, а НЛ (прежде всего ТАГ) и ФСП - в верхушке и в середине (табл. 1). Сравнение распределения липидов в зонах пластины $S$. japonica [7] показало, что у нее содержание ГЛ уменьшалось от верхней к нижней зоне пластины. Динамика распределения ФЛ в листе была сходной - накопление их происходило в меристеме. Содержание НЛ в середине пластины S. јаропіса было в 2 раза выше, чем в других ее частях, тогда как в $S$. cichorioides содержание НЛ, особенно ТАГ, плавно понижалось от верхушки пластины к его меристеме (табл. 1). Распределение отдельных классов ГЛ в сахаринах также имело различия: если в $S$. cichorioides МГДГ и СХДГ преобладали в середине пластины и в меристеме (табл. 1), то в $S$. japonica первые концентрировались в меристеме и в верхушке, а вторые - в верхушке и в середине пластины [7]. Содержание ДГДГ в $S$. japonica было выше и локализовались они преимущественно в верхушке и в середине пластины, тогда как в S. cichorioides - в меристеме. Такие различия могли быть видовыми или объясняться фрагментарной (по 10 см) методикой отбора участков в каждой части листа S. japonica [7].

В водорослях июня, в отличие от водорослей марта, содержание СХДГ было выше во всех зонах пластины. В водорослях и в высших растениях СХДГ локализованы в хлоропластах, где они выполняют структурную роль, обеспечивают взаимодействие с молекулами хлорофилла, способствуя их ориентации в мембранах [16]. Показана корреляция между уровнем хлорофиллов и СХДГ, выражающаяся в увеличении его концентрации в зрелых хлоропластах [17], где он необходим для функционирования ФС II. Наряду со структурными функциями СХДГ выполняют регуляторную роль в каталитической активности белков [18]. Накопление СХДГ в зрелых водорослях, скорее всего, связано с его многофункциональностью. 
Таблица 1. Содержание липидов и пигментов (в \% от СЛ) в разных частях таллома сахарин Японского моря

\begin{tabular}{|c|c|c|c|c|c|c|c|c|c|c|c|c|}
\hline \multirow{3}{*}{ Вещества } & \multicolumn{8}{|c|}{ S. cichorioides } & \multirow{2}{*}{\multicolumn{4}{|c|}{$\begin{array}{c}\text { S. angustata } \\
\text { август }\end{array}$}} \\
\hline & \multicolumn{4}{|c|}{ март } & \multicolumn{4}{|c|}{ июнь } & & & & \\
\hline & $1 *$ & $2 *$ & $3 *$ & $4 *$ & 1 & 2 & 3 & 4 & 1 & 2 & 3 & 4 \\
\hline $\begin{array}{l}\text { СЛ, \% от сырого } \\
\text { веса водоросли }\end{array}$ & 0,12 & 0,17 & 0,22 & 0,47 & 0,15 & 0,23 & 0,54 & 0,40 & 0,65 & 0,79 & 0,50 & 0,54 \\
\hline$\sum \underline{\Gamma Л}$ & $\underline{42,0}$ & $\underline{38,7}$ & $\underline{37,9}$ & $\underline{32,9}$ & $\underline{37,4}$ & $\underline{42,0}$ & $\underline{47,4}$ & $\underline{36,5}$ & $\underline{28,5}$ & $\underline{25,5}$ & $\underline{20,4}$ & $\underline{18,2}$ \\
\hline МГДГ & 21,9 & 19,0 & 18,7 & 15,7 & 15,9 & 19,3 & 17,2 & 15,5 & 10,3 & 10,1 & 6,9 & 7,0 \\
\hline ДГДГ & 7,8 & 7,6 & 8,0 & 6,8 & 8,6 & 8,6 & 13,8 & 8,8 & 7,8 & 8,1 & 4,6 & 3,5 \\
\hline СХДГ & 12,3 & 12,1 & 11,2 & 10,4 & 12,9 & 14,1 & 16,4 & 12,8 & 10,4 & 7,3 & 8,9 & 7,7 \\
\hline$\sum \Phi Л$ & $\underline{6,2}$ & $\underline{8,1}$ & $\underline{12,9}$ & $\underline{11,5}$ & $\underline{6,7}$ & $\underline{11,4}$ & $\underline{14,3}$ & $\underline{10,3}$ & $\underline{2,0}$ & $\underline{0,6}$ & $\underline{3,7}$ & $\underline{5,8}$ \\
\hline$\sum \underline{\mathrm{H} \Omega}$ & $\underline{12,8}$ & $\underline{16,4}$ & $\underline{15,8}$ & $\underline{32,0}$ & $\underline{18,9}$ & $\underline{14,8}$ & $\underline{12,9}$ & $\underline{27,2}$ & $\underline{9,2}$ & $\underline{38,2}$ & $\underline{40,5}$ & $\underline{56,2}$ \\
\hline ТАГ & 6,8 & 9,1 & 9,1 & 20,7 & 12,8 & 10,8 & 7,8 & 21,7 & 5,9 & 27,3 & 27,9 & 41,2 \\
\hline СЖК & 1,9 & 2,0 & 1,0 & 1,6 & 2,2 & 1,2 & 3,4 & 1,9 & 1,4 & 2,2 & 2,4 & 2,2 \\
\hline CCT & 4,1 & 5,3 & 5,7 & 9,7 & 3,9 & 2,8 & 1,7 & 3,6 & 1,9 & 8,7 & 10,2 & 12,8 \\
\hline$\sum \Phi C \Pi$ & $\underline{39,0}$ & $\underline{36,8}$ & $\underline{33,4}$ & $\underline{23,6}$ & $\underline{37,0}$ & $\underline{31,8}$ & $\underline{25,4}$ & $\underline{26,0}$ & $\underline{60,3}$ & $\underline{35,7}$ & $\underline{35,4}$ & $\underline{19,8}$ \\
\hline Хлорофиллы & 22,9 & 24,3 & 22,5 & 19,1 & 26,5 & 21,2 & 17,2 & 18,5 & 39,6 & 21,9 & 23,8 & 9,2 \\
\hline Каротиноиды & 16,1 & 12,5 & 10,9 & 4,5 & 10,5 & 10,6 & 8,2 & 7,5 & 20,7 & 13,8 & 11,6 & 10,6 \\
\hline
\end{tabular}

* 1 - апикальная часть, 2 - середина пластины, 3 - интеркалярная меристема, 4 - стволик с ризоидами.

Таблица 2. Содержание липидов и пигментов (в \% от СЛ) в разных частях таллома сахарин Охотского моря

\begin{tabular}{|c|c|c|c|c|c|c|c|}
\hline \multirow{2}{*}{ Вещества } & \multicolumn{3}{|c|}{ S. dentigera } & \multicolumn{4}{|c|}{ S. bongardiana } \\
\hline & $1+2 *$ & 3 & 4 & $1 *$ & $2 *$ & $3 *$ & $4 *$ \\
\hline $\begin{array}{c}\text { СЛ, \% } \\
\text { от сырого веса }\end{array}$ & 1,14 & 0,69 & 0,21 & 0,52 & 0,58 & 1,10 & 0,24 \\
\hline$\sum \Gamma Л$ & $\underline{33,3}$ & $\underline{30,2}$ & 29,5 & $\underline{36,9}$ & $\underline{34,8}$ & $\underline{34,0}$ & 29,9 \\
\hline МГдГ & 12,6 & 11,7 & 10,1 & 14,7 & 13,3 & 14,2 & 10,1 \\
\hline дгдГ & 8,2 & 7,8 & 8,3 & 10,5 & 10,2 & 9,3 & 10,0 \\
\hline СХДГ & 12,5 & 10,7 & 11,1 & 14,7 & 11,3 & 10,5 & 9,8 \\
\hline$\sum \Phi Л$ & 1,7 & 2,3 & $\underline{5,0}$ & $\underline{4,0}$ & $\underline{3,2}$ & 4,1 & $\underline{5,4}$ \\
\hline$\sum \underline{\mathrm{H}}$ & $\overline{11,9}$ & $\underline{28,9}$ & $\underline{43,3}$ & $\underline{20,2}$ & $\underline{24,1}$ & $\underline{32,2}$ & $\underline{44,5}$ \\
\hline ТАГ & $\overline{4,9}$ & $\overline{12,7}$ & $\overline{19,8}$ & $\overline{9,2}$ & $\overline{11,4}$ & $\overline{18,3}$ & $\overline{29,0}$ \\
\hline СЖК & 1,4 & 2,1 & 8,6 & 3,9 & 4,6 & 6,1 & 6,8 \\
\hline ССТ & 5,6 & 14,1 & 14,9 & 7,1 & 8,1 & 7,8 & 8,7 \\
\hline ¿ФСП: & $\underline{53,1}$ & $\underline{38,6}$ & $\underline{22,2}$ & $\underline{38,9}$ & $\underline{37,9}$ & $\underline{29,7}$ & $\underline{20,2}$ \\
\hline Хлорофиллы & $\overline{42,4}$ & $\overline{31,5}$ & $\overline{17,2}$ & $\overline{31,2}$ & $\overline{29,6}$ & $\overline{21,8}$ & $\overline{14,5}$ \\
\hline Каротиноиды & 10,7 & 7,1 & 5,0 & 7,7 & 8,3 & 7,9 & 5,7 \\
\hline
\end{tabular}

* 1+2 пластина с остатками апикальной части, 1 - апикальная часть, 2 - середина пластины, 3 - интеркалярная меристема, 4 - стволик с ризоидами.

B S. cichorioides в июне, как и в марте, была обнаружена высокая концентрация хлорофиллов. Однако в июне уровень хлорофиллов был выше в апикальной части и в середине пластины. Содержание же каротиноидов было почти в 2-2,5 раза ниже, как и в водорослях марта (табл. 1). В S. japonica (Желтое море, температура воды около $10^{\circ} \mathrm{C}$ ) верхушка пластины также имела более высокое содержание хлорофиллов, а содержание каротиноидов было немного ниже, чем в его середине [5]. Высокий уровень хлорофиллов и общей концентрации пигментов летом был обнаружен в Laminaria digitata, что объяснялось замедленным ростом в зоне меристемы [4]. В L. saccharina нашли увеличение количества главных светособирающих пигментов, и особенно, хлорофилла а [19], так и обратное [20], указывая на разные стратегии фотоакклимации, которые могут наблюдаться между видами и внутри одного вида из разных мест обитания. Как полагают, для компенсации температурных эффектов водоросли используют изменения в составе ФСП и их концентрации [19] и изменения в структурном составе мембран тилакоидов для поддержания их целостности и оптимальной текучести [21].

У микроводорослей ТАГ интенсивно синтезируются на сильном свету, и их накопление препятствует делению клеток, замедляя рост микроводорослей [22]. ТАГ могут являться строительными блоками для синтеза полярных липидов мембран хлоропластов при перестройках $Ф С$ аппарата [22]. Не исключена аналогичная роль ТАГ и у макроводорослей. Весной в более старой части листа (меристема) содержание ТАГ и ФЛ, необходимых для формирования новых тканей, было больше. В июне же, когда водоросль завершает рост, ТАГ в большей степени концентрировались в молодых частях таллома. Можно отметить, что накопление ГЛ 
и ФЛ в большей степени происходило в нижней части пластины и в его середине. В фазе зрелости, как правило, спороношение также охватывает нижнюю часть пластины и по мере созревания водоросли фертильная ткань передвигается к середине. В стволике с ризоидами S. cichorioides в марте и в июне присутствовали все классы липидов и ФСП, однако концентрация их была ниже, чем в зонах пластины, за исключением НЛ и ФЛ. Содержание ТАГ в стволике с ризоидами было в 2-3 раза выше, чем в зонах пластины, независимо от сезона (табл. 1). Стволики с ризоидами играли роль хранилища запасных веществ, таких как ТАГ. Значительное содержание ФЛ в них можно объяснить большим объемом не фотосинтезирующих тканей.

Водоросль S. angustata с цельной пластиной, растущую на камнях в прибойной зоне, собирали в августе - месяце, оптимальном для фотосинтеза и запасания веществ (температура воды 22-23 ${ }^{\circ} \mathrm{C}$ ). B S. Angustata содержание липидов было значительно выше, чем в S. cichorioides. Накопление липидов в большей степени происходило в середине пластины, в апикальной части, а в меристеме оно было самым низким (табл. 1). В липидах преобладали ТАГ. Их накопление шло в середине пластины и в меристеме. В верхушке концентрировались в значительной степени ГЛ и ФСП (табл. 1). В середине пластины и в меристеме содержание ГЛ и ФСП было близким, но ниже, чем в верхушке. Распределение отдельных классов ГЛ в зонах пластины отличалось от такового в S. cichorioides (табл. 1) и в S. japonica [7] - в верхушке концентрировались в равной степени МГДГ и СХДГ, в середине пластины преобладали МГДГ, в меристеме СХДГ. ДГДГ были локализованы в середине пластины и в верхушке. ФЛ в большей степени были в зоне меристемы. Стволик с ризоидами накапливал в основном ТАГ, и заметное количество ФЛ (табл. 1).

Вторая группа сахарин включала 2 водоросли с рассеченными на лопасти пластинами - S. dentigera и S. bongardiana (табл. 2). Водоросли собирали в первой половине августа. Апикальная часть пластины S. dentigera была обтрепана, поэтому брали листовую пластину вместе с остатками верхушки и отдельно меристему. Концентрация СЛ в этих частях пластины различалась, также как и у водорослей, описанных выше. В меристеме содержание СЛ было практически в 2 раза ниже, чем в зоне пластины (табл. 2). Возможно, это было связано с окончанием роста и репродукции, которая у нее происходит ранней весной. Стволик с ризоидами был наиболее беден липидами (табл. 2). Содержание ГЛ, их отдельных классов, как и содержание хлорофиллов и каротиноидов, было несколько выше в пластине (табл. 2), что обеспечивало высокий уровень фотосинтетической активности. Основные различия наблюдали в содержании НЛ, и, прежде всего, ТАГ: в меристеме их концентрация была примерно в 2,5 раза выше, чем в пластине. Свободные стерины концентрировались в меристеме и в стволике. В последнем было также много ТАГ, свободных жирных кислот и ФЛ (табл. 2).

Таблица 3. Состав жирных кислот (\% от их суммы) в разных частях таллома сахарин Японского моря

\begin{tabular}{|c|c|c|c|c|c|c|c|c|c|c|c|c|}
\hline \multirow{3}{*}{$\begin{array}{c}\text { Жирные кис- } \\
\text { лоты }\end{array}$} & \multicolumn{8}{|c|}{ S.cichorioides } & \multirow{2}{*}{\multicolumn{4}{|c|}{$\begin{array}{c}\text { L. angustata } \\
\text { август }\end{array}$}} \\
\hline & \multicolumn{4}{|c|}{ март } & \multicolumn{4}{|c|}{ июнь } & & & & \\
\hline & $1 *$ & $2 *$ & $3 *$ & $4 *$ & 1 & 2 & 3 & 4 & 1 & 2 & 3 & 4 \\
\hline $14: 0$ & 12,1 & 10,6 & 9,8 & 8,1 & 6,3 & 6,2 & 8,4 & 7,8 & 11,2 & 9,2 & 11,4 & 10,2 \\
\hline $15: 0$ & 0,3 & 0,3 & 0,4 & 0,4 & 0,2 & 0,2 & 0,4 & 0,5 & 0,1 & 0,1 & 0,2 & 0,5 \\
\hline $16: 0$ & 29,9 & 24,8 & 25,2 & 24,1 & 22,3 & 20,6 & 27,2 & 28,1 & 25,7 & 27,0 & 29,8 & 33,9 \\
\hline $16: 1 \mathrm{n}-7$ & 6,4 & 6,2 & 5,9 & 3,2 & 5,8 & 6,0 & 6,2 & 7,6 & 6,5 & 5,9 & 3,7 & 3,6 \\
\hline 18:0 & 1,1 & 0,9 & 1,1 & 1,2 & 1,5 & 1,4 & 2,0 & 2,5 & 2,0 & 1,4 & 2,1 & 2,9 \\
\hline $18: 1 \mathrm{n}-9$ & 9,7 & 13,8 & 13,6 & 10,9 & 10,6 & 14,9 & 13,9 & 9,9 & 20,1 & 21,5 & 18,2 & 16,9 \\
\hline $18: 1 \mathrm{n}-7$ & 1,2 & 1,1 & 1,6 & 1,5 & 0,5 & 1,0 & 0,3 & 1,7 & 0,5 & 1,1 & 1,3 & 0,6 \\
\hline $18: 2 n-6$ & 7,8 & 8,2 & 7,5 & 14,1 & 11,4 & 10,2 & 8,7 & 8,9 & 6,7 & 6,1 & 6,2 & 6,2 \\
\hline $18: 3 n-6$ & 0,7 & 1,1 & 3,0 & 2,0 & 4,8 & 5,3 & 3,0 & 0,4 & 0,2 & 0,4 & 0,4 & 0,1 \\
\hline $18: 3 n-3$ & 4,6 & 6,4 & 5,6 & 5,1 & 4,8 & 4,0 & 4,3 & 4,5 & 3,3 & 3,5 & 3,7 & 2,8 \\
\hline $18: 4 n-3$ & 6,4 & 7,0 & 8,6 & 7,3 & 5,2 & 5,7 & 3,1 & 2,2 & 4,7 & 5,1 & 4,9 & 4,3 \\
\hline $20: 0$ & 0,6 & 0,8 & 0,4 & 0,6 & 0,3 & 0,5 & 0,2 & 0,7 & 0,5 & 0,1 & 0,3 & 0,5 \\
\hline $20: 4 n-6$ & 11,1 & 10,8 & 9,8 & 14,9 & 15,8 & 14,2 & 13,0 & 17,3 & 9,2 & 9,0 & 9,1 & 10,9 \\
\hline $20: 5 n-3$ & 8,1 & 8,0 & 7,5 & 6,6 & 10,5 & 8,9 & 9,3 & 7,9 & 9,3 & 9,6 & 8,7 & 6,6 \\
\hline$\sum$ НЖК & 44,0 & 37,4 & 36,9 & 34,4 & 30,6 & 29,8 & 38,2 & 39,6 & 39,5 & 37,8 & 43,8 & 48,0 \\
\hline$\Sigma$ МНЖК & 17,3 & 21,1 & 21,1 & 15,6 & 16,9 & 21,9 & 20,4 & 19,2 & 27,1 & 28,5 & 23,2 & 21,1 \\
\hline$\sum$ ПНЖК n-3 & 19,1 & 21,4 & 21,7 & 19,0 & 20,5 & 18,6 & 16,7 & 14,6 & 16,3 & 18,2 & 17,3 & 13,7 \\
\hline ПНЖК n-6 & 19,6 & 20,1 & 20,3 & 31,0 & 32,0 & 29,7 & 24,7 & 26,6 & 17,1 & 15,5 & 15,7 & 17,2 \\
\hline
\end{tabular}

* сокращения приведены в таблице 1. 
Таблица 4. Состав жирных кислот (\% от их суммы) в разных частях таллома сахарин Охотского моря

\begin{tabular}{|c|c|c|c|c|c|c|c|}
\hline \multirow{2}{*}{ ЖК } & \multicolumn{3}{|c|}{ S. dentigera } & \multicolumn{4}{|c|}{ S. bongardiana } \\
\hline & $1+2^{*}$ & $3 *$ & $4 *$ & $1 *$ & $2 *$ & $3 *$ & $4 *$ \\
\hline $14: 0$ & 6,9 & 8,7 & 7,5 & 7,2 & 8,8 & 10,7 & 10,4 \\
\hline $15: 0$ & 0,6 & 0,5 & 1,5 & 1,1 & 0,8 & 0,9 & 1,0 \\
\hline $16: 0$ & 37,1 & 38,1 & 35,6 & 24,7 & 20,0 & 21,4 & 24,0 \\
\hline $16: 1 \mathrm{n}-7$ & 3,5 & 5,3 & 3,2 & 5,4 & 4,9 & 4,9 & 6,3 \\
\hline $18: 0$ & 1,2 & 1,5 & 1,0 & 1,7 & 1,9 & 3,0 & 4,9 \\
\hline $18: 1 \mathrm{n}-9$ & 11,9 & 15,3 & 20,5 & 12,0 & 17,6 & 16,3 & 14,6 \\
\hline $18: 2 n-6$ & 5,3 & 2,7 & 5,0 & 4,0 & 6,1 & 6,3 & 2,5 \\
\hline $18: 3 n-6$ & 2,5 & 1,0 & 0,5 & 0,7 & 0,5 & 0,2 & 0,2 \\
\hline $18: 3 n-3$ & 4,3 & 3,9 & 2,7 & 4,8 & 5,6 & 4,3 & 2,8 \\
\hline $18: 4 n-3$ & 8,5 & 6,1 & 5,7 & 12,7 & 12,1 & 10,8 & 9,3 \\
\hline $20: 0$ & 0,2 & 0,1 & 1,3 & 0,7 & 1,1 & 0,9 & 1,2 \\
\hline $20: 4 n-6$ & 8,3 & 8,0 & 9,6 & 10,4 & 9,2 & 10,7 & 13,4 \\
\hline $20: 5 n-3$ & 9,7 & 8,8 & 5,9 & 14,6 & 11,4 & 9,6 & 9,4 \\
\hline$\sum$ НЖК & 46,0 & 48,9 & 46,9 & 35,4 & 32,6 & 36,9 & 41,5 \\
\hline$\sum$ МНЖК & 15,4 & 20,6 & 23,7 & 17,4 & 22,5 & 21,2 & 20,9 \\
\hline$\sum$ ПНЖК n-3 & 22,5 & 18,8 & 14,3 & 32,1 & 29,1 & 24,7 & 21,5 \\
\hline$\sum$ ПНЖК n-6 & 16,1 & 11,7 & 15,1 & 15,1 & 15,8 & 17,2 & 16,1 \\
\hline
\end{tabular}

* значения приведены в таблице 2 .

У S. bongardiana спороношение растянуто во времени и имеет два пика - ранневесенний и летнеосенний. На стадии спорообразования водоросль формирует цельную пластину, которая вновь становится рассеченной в ходе подготовки к зимнему покою. В период исследования водоросль имела рассеченную пластину и не спороносила. В отличие от S. dentigera основная концентрация липидов в S. bongardiana была в меристеме, а апикальная часть и середина пластины содержали их в 2 раза меньше (табл. 2). Содержание ГЛ немного увеличивалось от меристемы к верхушке пластины. ФЛ было немного больше в меристеме и в верхушке (табл. 2). Концентрация НЛ увеличивалась от апикальной зоны к меристеме, где содержание ТАГ было в 2 раза выше, чем в верхушке. Меристема содержала довольно много свободных жирных кислот (табл. 2). ФСП были локализованы в большей степени в апикальной зоне. В обоих дигитатных сахаринах содержание каротиноидов было значительно ниже, чем в сахаринах Японского моря. Стволик с ризоидами, как и у других сахарин, был богат НЛ, прежде всего ТАГ (табл. 2).

В распределении ЖК по зонам листовой пластины также обнаружили значительные различия. В S. cichorioides, собранной в марте, наблюдали увеличение содержания НЖК от меристемы к апикальной части, в то время как содержание МНЖК и ПНЖК было выше в середине пластины и в меристеме (табл. 3). Содержание ПНЖК (n-3)- и ПНЖК (n-6)-серий было примерно одинаковым в этих зонах пластины. У июньских образцов водоросли содержание НЖК убывало от меристемы к апикальной зоне, а МНЖК, также как и в мартовских водорослях, были локализованы в основном в середине и в меристеме. Содержание ПНЖК убывало от апикальной зоны к меристеме. Содержание ПНЖК (n-6)-серии было выше содержания ПНЖК (n-3)серии во всех частях пластины. В ранее исследованной $S$. јаропіса содержание НЖК было ниже, чем в S. cichorioides, и в зонах пластины они были распределены относительно равномерно [7], в то время как в S. cichorioides их локализация была заметно выше в меристеме и в стволике. МНЖК, как и в S. cichorioides были локализованы в основном в середине пластины. Более заметны были различия в содержании и распределении ПНЖК (n-6)-серии. Доля этих кислот в $S$. cichorioides росла от меристемы к апикальной части (табл. 3), тогда как в S. јароnica они были локализованы в нижней части пластины и в его середине [7]. Уровень ПНЖК (n-3)-серии был выше в S. japonica, а концентрировались они одинаково в верхушке пластины и в его середине. Основными по содержанию во всех зонах листа обеих сахарин были 16:0, 18:1 n-9, 18:2 n-6, 20:4 n-6, 20:5 n-3 (табл. 3). В ЖК стволика с ризоидами S. cichorioides основная доля приходилась на НЖК и ПНЖК (n-6)-серии (табл. 3). Накопление 20:4 n-6 в стволике бурых водорослей было показано ранее [9, 10]. B S. angustata НЖК концентрировались в основном в меристеме и в верхушке пластины, а МНЖК были сосредоточены в середине пластины и в его верхушке (табл. 3). ПНЖК (n-3)-серии были локализованы в основном в середине пластины и в меристеме, а ПНЖК (n-6)-серии в верхушке. В стволике с ризоидами содержание НЖК и ННЖК было почти равным (табл. 3).

В сахаринах Охотского моря распределение ЖК по таллому имело также видовые различия и определялось распределением классов липидов по таллому. Во всех частях таллома была высока доля НЖК. МНЖК, как и ПНЖК (n-6)-серии, были сосредоточены в базальной части таллома, а ПНЖК (n-3)-серии в пластине выше меристемы (табл. 4). 


\section{Заключение}

Таким образом, характер изменений в содержании липидов и ФСП в зонах пластины имел видовые особенности и зависел от сезона и места сбора водорослей. В сахаринах Охотского и Японского морей содержание общих липидов было высоким в теплое время года во всех частях пластины. В накоплении ФСП в S. cichorioides Японского моря прослеживались сезонные изменения: ранней весной суммарное содержание хлорофиллов и каротиноидов в зонах пластины было выше, чем в летних образцах водоросли. В сахаринах Японского моря было значительно выше содержание каротиноидов, чем в сахаринах Охотского моря. Общим для всех сахарин было преобладание ГЛ во всех частях пластины: концентрация их зависела от вида, места обитания и сезона сбора водоросли. Содержание ФЛ в исследованных водорослях Японского моря было выше, чем в сахаринах Охотского моря. Они были локализованы в основном в меристеме и в стволике с ризоидами. У исследованных дигитатных водорослей Охотского моря НЛ локализовались в меристеме и в стволике. В сахаринах Японского моря локализация НЛ и уровень их содержания в зонах пластины определялся сезонностью, в стволике же накопление НЛ (в частности ТАГ) происходило, независимо от сезона и вида водоросли. Накопление ТАГ в меристеме сахарин происходило в растущих водорослях, а уменьшение его содержания было связано с завершением роста. В сахаринах Охотского моря, обитающих в более холодных водах, как и в сахарине S. angustata Японского моря, растущей в прибойной зоне, обнаружили более высокое содержание свободных стеринов в меристеме, в середине пластины и в стволике. Распределение ЖК по таллому и соотношение их молекулярных видов в каждой водоросли имело свои видовые особенности и определялось условиями обитания и стадией развития водоросли, скорее, чем морфологией таллома. Все части таллома сахарин содержали высокую долю НЖК, однако в сумме ЖК всегда преобладали ННЖК, большую часть которых составляли ПНЖК. Накопление ПНЖК (n-3)серии считают необходимым для изменения текучести мембран тилакоидов, в которых тем самым ускоряется движение электронов, обеспечивая максимальную эффективность фотосинтеза [23]. Как показано, существует определенная связь между содержанием хлорофиллов и 20:5 n-3: понижение ее содержания соотносится с понижением содержания хлорофилла $\alpha$ [24]. Уменьшение содержания 20:5 n-3 в сахаринах, как правило, соотносилось со снижением содержания хлорофиллов в зонах листа.

Вещества, представленные в работе, имеют практический интерес из-за высокой биологической активности и перспектив использования их в медицине [10, 25, 26].

Благодарности. Авторы выражают благодарность старшему научному сотруднику Анне Владимировне Скрипцовой (Институт биологии моря им. А.В. Жирмунского, ДВО РАН, Владивосток) за определение водорослей.

\section{Список литературы}

1. Flores-Moya A., Fernandez J.A., Niell F.X. Seasonal Variation of Photosynthetic Pigments, Total C, N, and P Content, and Photosynthesis in Phyllariopsis purpurascens (Phaeophyta) from the Strait of Gibraltar // J. Phycol. 1995. Vol. 31, N6. Pp. 867-874.

2. Gomez I., Wiencke C. Seasonal Changes in C, N and Major Organic Compounds and Their Significance to Morphofunctional Processes in the Endemic Antarctic Brown Alga Ascoseira mirabilis // Polar. Biol. 1998. Vol. 19, N2. Pp. 115-124.

3. Gevaert F., Davoult D., Creach A., Kling R., Janquin M.-A., Seuront L., Lemone Y. Carbon and Nitrogen Content of Laminaria saccharina in the Eastern English Channel: Biometrics and Seasonal Variations // J. Mar. Biol. Assoc. U.K. 2001. Vol. 81, N5. Pp. 727-734.

4. Delebecq G., Davoult D., Menu D., Janquin M.-A.,Dauvin J.-C., Gevaert F. Influence of Local Environmental Conditions on the Seasonal Acclimation Process and the Daily Integrated Production Rates of Laminaria digitata (Phaeophyta) in the English Channel // Mar. Biol. 2013. Vol. 160, N3. Pp. 503-517.

5. Wang Y., Xu D., Fan X., Zhang X., Ye N., Wang W., Mao Y., Mou S., Cao S. Variation of Photosynthetic Performance, Nutrient Uptake, and Elemental Composition of Different Generations and Different Thallus Parts of Saccharina japonica // J. Appl. Phycol. 2013. Vol. 25, N2. Pp. 631-637.

6. Gomez I., Wiencke C., Thomas D.N. Variations in Photosynthetic Characteristics of the Antarctic Marine Brown Alga Ascoseira mirabilis in Relation to Tallus Age and Size // Eur. J. Phycol. 1996. Vol. 31, N2, Pp. 167-172.

7. Khotimchenko S.V., Kulikova I.V. Lipids of Different Parts of the Lamina of Laminaria japonica Aresch. // Bot. Mar. 2000. Vol. 43, N1. Pp. 87-91.

8. Kulikova I.V., Khotimchenko S.V. Lipids of Different Parts of the Thallus of Brown Alga Sargassum miyabei from Sea of Japan // Russ. J. Mar. Biol. 2000. Vol. 26, N1. Pp. 55-57. 
9. Miralles J., Aknin M., Bandia J., Bassene E., Diagne O., Kornprobst J.-M. Particularites de la Composition en Lipids et en Glucides d'une Laminaire Profonde des Cotes Senegalaises Ecklonia muratii Feldman // Oceanologica Acta. 1989. Vol. 12, N4. Pp. 433-436.

10. Khan M.N.A., Cho J.-Y., Lee M.-C., Kang J.-Y., Park N.G., Fujii H., Hong Y.-K. Isolation of Two Antiinflammatory and One Pro-inflammatory Polyunsaturated Fatty Acids From the Brown Seaweed Undaria pinnatifida // J. Agric. Food Chem. 2007. Vol. 55, N17. Pp. 6984-6988.

11. Bligh E.G., Dyer W.J. A Rapid Method of Total Lipid Extraction and Purification // Can. J. Biochem. Physiol. 1959. Vol. 37, N8. Pp. 911-918.

12. Герасименко Н.И., Скрипцова А.В., Бусарова Н.Г., Моисеенко О.П. Влияние сезона и стадии роста на содержание липидов и фотосинтетических пигментов у бурой водоросли Undaria pinnatifida (Harvey) Suringar (Phaeophyceae, Alariaceae) // Физиология растений. 2011. Т. 58, №5. С. 743-749.

13. Christie W.W. Equivalent Chain Length of Methyl Ester Derivatives of Fatty Acids on Gas Chromatography // J. Chromatogr. 1988. Vol. 447. Pp. 305-314.

14. Jensen A., Indergaard M., Holt T.J. Seasonal Variation in the Chemical Composition of Saccorhiza polyschides (Laminariales, Phaeophyceae) // Bot. Mar. 1985. Vol. 28, N9. Pp. 375-381.

15. Drew E.A. Physiology of Laminaria. 11. Seasonal Variation and Respiration in Laminaria digitata Lamour, L. hyperborea (Gunn.) Fosl. and L. saccharina (L.) Lamour and a Model for Calculation of Annual Carbon Budgets // P.S.Z.N.I.: Mar. Ecol. 1983. Vol. 4, N3. Pp. 227-250.

16. Benson A.A. Plant Membrane Lipids // Annu. Rev. Plant Physiol. 1964. Vol. 15. Pp. 1-16.

17. Leech R.M., Rumsby M.G., Thomson W.W. Plastid Differentiation, Acyl Lipid, and Fatty Acid Changes in Developing Green Maize Leaves // Plant Physiol. 1973. Vol. 52, N3. Pp. 240-245.

18. Vishwanath B.S., Eichenberger W., Frey F.J., Frey B.M. Interaction of Plant Lipids with 14 kDa Phospholipase A Enzymes // Biochem. J. 1996. Vol. 320, N1. Pp. 93-99.

19. Machalek K.M., Davison I.R., Falkowski P.G. Thermal Acclimation and Photoacclimation of Photosynthesis in the Brown Alga Laminaria saccharina // Plant Cell Environ. 1996. Vol. 19, N9. Pp. 1005-1016.

20. Gevaert F., Creach A., Davoult D., Holl A.-C., Seuront L., Lemone Y. Photo-inhibition and Seasonal Photosynthetic Performance of the Seaweed Laminaria saccharina During a Simulated Tidal Cycle: Chlorophyll Fluorescence Measurements and Pigment Analysis // Plant Cell Environ. 2002. Vol. 25, N7. Pp. 859-872.

21. Zheng G., Tian B., Fujuan Z., Tao F., Li W. Plant Adaptation to Frequent Alteration Between High and Low Temperatures: Remodeling of Membrane Lipids and Maintenance of Unsaturation Levels // Plant Cell Environ. 2011. Vol. 34, N9. Pp. 1431-1442.

22. Соловченко А.Е. Физиологическая роль накопления нейтральных липидов эукариотическими микроводорослями при стрессах // Физиология растений. 2012. Т. 59, №2. С. 192-202.

23. Mock T., Kroon B.M.A. Photosynthetic Energy Conversion under Extreme Conditions -I: Important Role of Lipids as Structural Modulators and Energy Sink under N-limited Growth in Antarctic Sea Ice Diatoms // Phytochemistry. 2002. Vol. 61, N1. Pp. 41-51.

24. Cohen Z., Vonshak A., Richmond A. Effect of Environmental Conditions on Fatty Acid Composition of the Red Alga Porphyridium cruentum: Correlation to Growth Rate // J. Phycol. 1988. Vol. 24, N3. Pp. 328-332.

25. Banskota A.H., Stefanova R., Gallant P., McGinn P.J. Mono- and digalactosyldiacylglycerols: potent nitric oxide inhibitors from the marine microalga Nannochloropsis granulate // J. Appl. Phycol. 2013. Vol. 25, N2. Pp. 349-357.

26. Le Goff C., Kaux J-F., Leroy L., Pincemail J., Chapelle J-P., Cavalier E. Fatty acids and associated cardiovascular risk // Food Nutr. Sci. 2013. Vol. 4. Pp. 188-194.

Поступило в редакцию 6 октября 20142.

После переработки 25 ноября 2014 г. 
Gerasimenko N.I., Logvinov S.V., Busarova N.G. LIPIDS AND PHOTOSYNTHETIC PIGMENTS OF DIFFERENT ZONES OF THE THALLUS ALGAE OF THE GENUS SACCHARINA

G.B. Elakov Pacific Institute of Bioorganic Chemistry, Far Eastern Branch, Russian Academy of Sciences, pr. 100-letia Vladivostoka, 159, Vladivostok, 690022 (Russia),E-mail:gerana@piboc.dvo.ru

The distribution of lipids and photosynthetic pigments (PSP) in the different zones of blade as apical, middle and intercalary meristem, as well as in the stipe with rhizoids two species Saccharina of Japan sea: Saccharina cichorioides (Miyabe) and $S$. angustata (Kjellman) with tallus blade -like and two digitate species: S. dentigera (Kjellman) и S. bongardiana (Postels et Ruprecht) from Okhotsk sea were investigated. Variation in lipid content and PSP in zones of blade of S. cichorioides with starting of growth and it termination were investigated additionally. Significant differences in the distribution of total lipids (TL), their individual classes, fatty acids (FA) and PSP in different zones of the thallus were founded, which had the species peculiarities and determined by the conditions habitat and the stage of development of algae rather than the morphology of the thallus.

In algae $S$. cichorioides grow up completed, in contrast to algae started of growth, there was an increase in lipid content in all parts of the blade, but in the stipe with rhizoids lipid content was reduced. Along with this, there was a redistribution contents all classes of lipids and PSP, saturated (SFA) and unsaturated (USFA) FA in zones of the blade: the content of first decreases sharply in the apical part and in the middle of the blade, but USFA - increased. Such restructuring is likely to have been associated with the beginning of stage of sporogenesis.

Keywords: Saccharina, brown alga, fatty acids, glyceroglycolipids, phospholipids, triacylglycerols, photosynthetic pigments, free sterols, GC.

\section{References}

1. Flores-Moya A., Fernandez J.A., Niell F.X. J. Phycol., 1995, vol. 31, no. 6, pp. 867-874.

2. Gomez I., Wiencke C. Polar. Biol., 1998, vol. 19, no. 2, pp. 115-124.

3. Gevaert F., Davoult D., Creach A., Kling R., Janquin M.-A., Seuront L., Lemone Y. J. Mar. Biol. Assoc., U.K. 2001, vol. 81, no. 5, pp. 727-734.

4. Delebecq G., Davoult D., Menu D., Janquin M.-A.,Dauvin J.-C., Gevaert F. Mar. Biol., 2013, vol. 160, no. 3, pp. 503-517.

5. Wang Y., Xu D., Fan X., Zhang X., Ye N., Wang W., Mao Y., Mou S., Cao S. J. Appl. Phycol., 2013, vol. 25, no. 2, pp. 631-637.

6. Gomez I., Wiencke C., Thomas D.N. Eur. J. Phycol., 1996, vol. 31, no. 2, pp. 167-172.

7. Khotimchenko S.V., Kulikova I.V. Bot. Mar., 2000, vol. 43, no. 1, pp. 87-91.

8. Kulikova I.V., Khotimchenko S.V. Russ. J. Mar. Biol., 2000, vol. 26, no. 1, pp. 55-57.

9. Miralles J., Aknin M., Bandia J., Bassene E., Diagne O., Kornprobst J.-M. Oceanologica Acta, 1989, vol. 12, no. 4, pp. 433-436.

10. Khan M.N.A., Cho J.-Y., Lee M.-C., Kang J.-Y., Park N.G., Fujii H., Hong Y.-K. J. Agric. Food Chem., 2007, vol. 55, no. 17, pp. 6984-6988.

11. Bligh E.G., Dyer W.J. Can. J. Biochem. Physiol., 1959, vol. 37, no. 8, pp. 911-918.

12. Gerasimenko N.I., Skriptsova A.V., Busarova N.G., Moiseenko O.P. Fiziologiia rastenii, 2011, vol. 58, no. 5, pp. 743-749. (in Russ.).

13. Christie W.W. J. Chromatogr., 1988, vol. 447, pp. 305-314.

14. Jensen A., Indergaard M., Holt T.J. Bot. Mar., 1985, vol. 28, no. 9, pp. 375-381.

15. Drew E.A. P.S.Z.N.I.: Mar. Ecol., 1983, vol. 4, no. 3, pp. 227-250.

16. Benson A.A. Annu. Rev. Plant Physiol., 1964, vol. 15, pp. 1-16.

17. Leech R.M., Rumsby M.G., Thomson W.W. Plant Physiol., 1973, vol. 52, no. 3, pp. 240-245.

18. Vishwanath B.S., Eichenberger W., Frey F.J., Frey B.M. Biochem. J., 1996, vol. 320, no. 1, pp. 93-99.

19. Machalek K.M., Davison I.R., Falkowski P.G. Plant Cell Environ., 1996, vol. 19, no. 9, pp. 1005-1016.

20. Gevaert F., Creach A., Davoult D., Holl A.-C., Seuront L., Lemone Y. Plant Cell Environ., 2002, vol. 25, no. 7, pp. 859-872.

21. Zheng G., Tian B., Fujuan Z., Tao F., Li W. Plant Cell Environ., 2011, vol. 34, no. 9, pp. 1431-1442.

22. Solovchenko A.E. Fiziologiia rastenii, 2012, vol. 59, no. 2, pp. 192-202. (in Russ.).

23. Mock T., Kroon B.M.A. Phytochemistry, 2002, vol. 61, no. 1, pp. 41-51.

24. Cohen Z., Vonshak A., Richmond A. J. Phycol., 1988, vol. 24, no. 3, pp. 328-332.

25. Banskota A.H., Stefanova R., Gallant P., McGinn P.J. J. Appl. Phycol., 2013, vol. 25, no. 2, pp. 349-357.

26. Le Goff C., Kaux J-F., Leroy L., Pincemail J., Chapelle J-P., Cavalier E. Food Nutr. Sci., 2013, vol. 4, pp. $188-194$.

Received January 13, 2015

Revised March 23, 2015

\footnotetext{
* Corresponding author.
} 
